資 料

\title{
日本の獣医系大学における疫学教育の現状
}

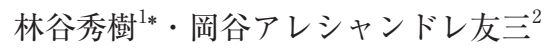 \\ ${ }^{1}$ 東京農工大学大学院 \\ 2 麻布大学獣医学部
}

\section{Current Status of Education for Veterinary Epidemiology in Japanese Veterinary School}

\author{
Hideki HAYASHIDANI ${ }^{1}$ and Alexandre Tomomitsu OKATANI ${ }^{2}$ \\ ${ }^{1}$ Institute of Agricultire, Tokyo University of Agriculture and Technology \\ ${ }^{2}$ School of Veterinary Medicine, Azabu University
}

\section{1.これまでの経緯}

1997 年に獣医疫学会が産声を挙げてから, 本学会がま ず取り組んできたことは，獣医学とその関連領域における (獣医）疫学の発展と普及を目的とした啓蒙活動であった。 特に, 発足当時, 獣医系大学で (獣医) 疫学の講義を独立 した科目として行なっていた大学はわずかに 3 大学しかな く, 獣医学教育の中で疫学という科目を独立の科目として 認知してもらうことが最も重要な活動の一つであった。も ち万ん, 当時も獣医学教育の中で疫学の教育は行なわれて いなかった訳でなく, 公衆衛生学, 獣医衛生学および獣医 伝染病学といった応用獣医学分野などの講義の中で, 疫学 はこれらの学問を支える方法論として位置づけられ，教育 は行われてきた。しかし, 応用獣医学に関する教育の中で は，それぞれの科目で必要な疫学の内容が断片的に取り出 された形で教育が行われてきたため, 疫学教育としては十 分に体系づけられておらず，応用獣医学分野以外の分野， たとえば臨床疫学などの疫学はほとんど教育されることは なかった。このような背景のもと，本学会では，(獣医) 疫学を獣医学教育の中で認知してもらうため，まず，2005 年に学会の総力を結集して, 獣医疫学の教科書 “獣医疫学” を出版し，(獣医）疫学を体系的にまとめるとともに, 大 学教育の中で疫学を教える際の入門書として活用してもら

連絡先 : 林谷秀樹*

東京農工大学大学院農学研究院動物生命科学部門

于183-8509 東京都府中市幸町 3-5-8

E-mail : eisei@cc.tuat.ac.jp
えるよう啓蒙活動を行なった。さらに, 2007 年には (獣医) 疫学教育のモデルとなるカリキュラムを本学会が提言し た。2011 年には, 全国大学獣医学関係代表者協議会が中 心となって, 獣医学生が卒業までに身につけるべき最低限 の修得内容を示した、 “獣医学教育モデル・コア・カリキュ ラム”が策定され，これまでの努力が実を結び，この中で 疫学が獣医学教育の中で応用獣医学教育分野 (8 科目) の 中で独立した 1 科目として選定された。これに伴い, 獣医 疫学会では, 2011 年に他教科に先駆けて獣医学分野では 初めてコア・カリキュラム準拠の教科書 “獣医疫学一基礎 から応用まで一第 2 版”を出版した。その後，2016 年に 始まった獣医学共用試験 $($ vetCBT ・ vetOSCE) の vetCBT においても, (獣医) 疫学はその出題科目の 1 つとなって いる。

\section{2. 我が国の獣医系大学における （獣医）疫学の講義の実施状況}

我が国の国公私立の獣医系 15 大学に扔ける（獣医）疫 学の講義の実施状況について, 2008 年に行なった調査 ${ }^{3)}$ では，(獣医）疫学を単独の科目として開講している大学 はわずかに 5 大学で，それ以外の 10 大学は，公衆衛生学 や獣医衛生学などの科目の中で (獣医) 疫学を教えていた。 2011 年に“獣医学教育モデル・コア・カリキュラム”が 策定され, (獣医) 疫学が正式に応用獣医学分野の独立し た 1 科目となったことを受けて, 各獣医系大学はカリキュ ラム改訂時に (獣医) 疫学を独立した科目として採用する ようになってきていることから，2016 年に改めて実態調 
表 1 日本の獣医系大学に扔ける（獣医）疫学講義の実施状況

\begin{tabular}{|c|c|c|c|c|c|c|}
\hline & \multirow{3}{*}{ 講義形態 } & \multirow{3}{*}{$\begin{array}{l}2008 \text { 年 } \\
\text { 大学数 }\end{array}$} & \multicolumn{4}{|c|}{2016 年 } \\
\hline & & & \multirow[b]{2}{*}{ 大学数 } & \multicolumn{3}{|c|}{ 専任·非常勤 } \\
\hline & & & & 専任 & $\begin{array}{l}\text { 専任 + } \\
\text { 非常勤 }\end{array}$ & 非常勤 \\
\hline 1 & (獣医) 疫学を単独で開講 & $5^{*}$ & $13^{*}$ & 9 & 3 & 1 \\
\hline \multirow[t]{7}{*}{2} & 獣医衛生学または公衆衛生学等の中で実施 & 10 & 2 & 2 & & \\
\hline & a. 公衆衛生学 & 5 & 1 & 1 & & \\
\hline & b. 獣医衛生学 & 1 & & & & \\
\hline & c. 獣医伝染病学 & 1 & & & & \\
\hline & d. 公衆衛生学 + 獣医衛生学 & 1 & 1 & 1 & & \\
\hline & e. 公衆衛生学+獣医伝染病学 & 1 & & & & \\
\hline & f. 公衆衛生学 + 獣医衛生学 + 獣医伝染病学 & 1 & & & & \\
\hline
\end{tabular}

*いずれも必修科目として実施

表 2 日本の獣医系大学における (獣医) 疫学演習 (実習) の実施状況

\begin{tabular}{clc}
\hline \multicolumn{2}{c}{ 演習形態 } & 大学数 \\
\hline (獣医) 疫学に関する演習 (実習) & を実施していない & 11 \\
(獣医) 疫学に関する演習 (実習) & を実施している & $4 *$ \\
\hline
\end{tabular}

*いずれも必修科目として実施

査を行なった。その結果, 2016 年には獣医系大学 15 大学 中 13 大学と, 2 校を除くほとんどの大学が (獣医) 疫学 を独立した科目として教育していた（表 1)。そして, 13 大学のいずれも(獣医) 疫学を必修科目として定めており, 講義単位も 2 単位（90 分授業で 15 回）程度教えているこ とが判明した。また, (獣医) 疫学を教えている教員も9 大学が尃任教員であり, 専任と非常勤と答えた 3 大学を加 えると，実に 12 大学に（獣医）疫学を教える専任の教員 がいることになる。この調查結果は, (獣医) 疫学が獣医 学教育の中で確固たる地位を固めつつあることを示してお り, 獣医学とその関連領域に打ける (獣医) 疫学の発展と 普及という本学会設立の目的は, 学会設立 20 年を得て, ようやく大学教育において達成しつつある。

\section{3. 我が国の獣医系大学における (獣医) 疫学の演習（実習）の実施状況}

(獣医) 疫学は, 予防獸医学を実践する実学であり, (獣 医）疫学の教育には疫学の理論だけでなく, その理論を現 場で応用できるような（獣医）疫学の演習や実習のような 実践教育が必須と考えられるが, “獣医学モデル・コア・ カリキュラム”に打いては, 疫学演習（実習）に関するコ
ア・カリキュラムは策定されておらず，(獣医）疫学が獣 医学教育の中でしっかり根付いてきた現在, 本学会の次の 目標は (獣医) 疫学演習 (実習) に関するコア・カリキュ ラムの策定と大学教育に拈ける実践であろう。一部の大学 ではすでに (獣医) 疫学演習を実施している大学もあるこ とから, 今回の調査ではその実態を調べた。その結果, 獣 医系大学 15 大学中 4 大学がすでに獣医疫学演習という科 目名で，いずれも必修科目として（獸医）疫学の演習を実 施していることが判明した（表2）。またその単位数は揖 おむね 1 単位（15 回）かそれ未満であった。まだ, “獣医 学モデル・コア・カリキュラム”の中に (獣医) 疫学演習 (実習) が策定されていない中, すでに一部の大学では獣 医疫学の演習科目が獣医学教育の中に取り入れられ, 実施 されていることは，今後学会が (獣医) 疫学演習を獣医学 教育に必須の科目として取り入れていく活動を推進してい く上で，大きな力を与えるものであり，これら大学の関係 者の方々の先見性とその努力に敬意を表したい。

\section{4. 今後の獣医疫学の実践教育の推進}

今後の（獣医）疫学教育のあるべき姿については，すで に (獣医) 疫学の講義は, 我が国の獣医学教育の中にしっ 
かりと定着してきたことから, 次は大学教育の中に（獣医） 疫学演習（実習）を新しい科目として打ち立てていくよう 本学会として推進していく必要がある。上述したように, いくつかの大学がその先鞭をつけているので, すでに獣医 疫学演習を実施している大学に所属する本学会の理事・幹 事が中心になって, 現在, (獣医) 疫学演習 (実習)のコ ア・カリキュラムを策定中である。しかし，(獣医）演習 (実習) を大学の新しい科目として打ち立てることは, 大 学によってはすぐには困難と思われるので, 現在, 全国大 学獣医学関係代表者協議会, 日本獣医師会, NOSAI 全国 などが「獣医学臨床教育推進機構 (仮称)」を設置して, 参加型臨床実習/公衆衛生・家畜衛生関連アドバンスト実 習等について検討を始めていることから, 公衆衛生・家畜 衛生関連アドバンスト実習の中で, (獣医) 疫学演習を行 なえるよう，これらに対応したカリキュラムを整備してい くことも必要となろう。また, 第 33 回獣医疫学会学術集 会でのシンポジウム4)でも取り上げたように, 現在, 国立 感染症研究所の実地疫学専門家養成コース (FETP) や動
物衛生研究所の獸医疫学特殊講習会, 岡山大と岡山理科大 とで実施している食中毒疫学研修会などが，(獣医）疫学 に関係する卒後の実践教育としてすでに継続的に実施され ている。このような卒後教育も (獣医) 疫学の実践教育の 中にどのように位置付けて活用していけばよいかなどにつ いて, 今後関係者の活発な議論が期待される。

\section{参考文献}

1）林谷秀樹 : 獣医疫学教育のカリキュラムについて。 獣 医疫学䧱誌，10，99-101，2007.

2）全国大学獣医学関係代表者協議会: 獣医学教育モデル・ コア・カリキュラム 平成 24 年度版, 近代出版, 東京, 2012.

3）林谷秀樹：日本における獣医疫学教育の現状. 獣医疫 学雑誌, 13, 4-7, 2009.

4) 林谷秀樹 : 獣医疫学の実践教育の必要性. 獣医疫学䧱 誌, 16, 97-99, 2012. 